
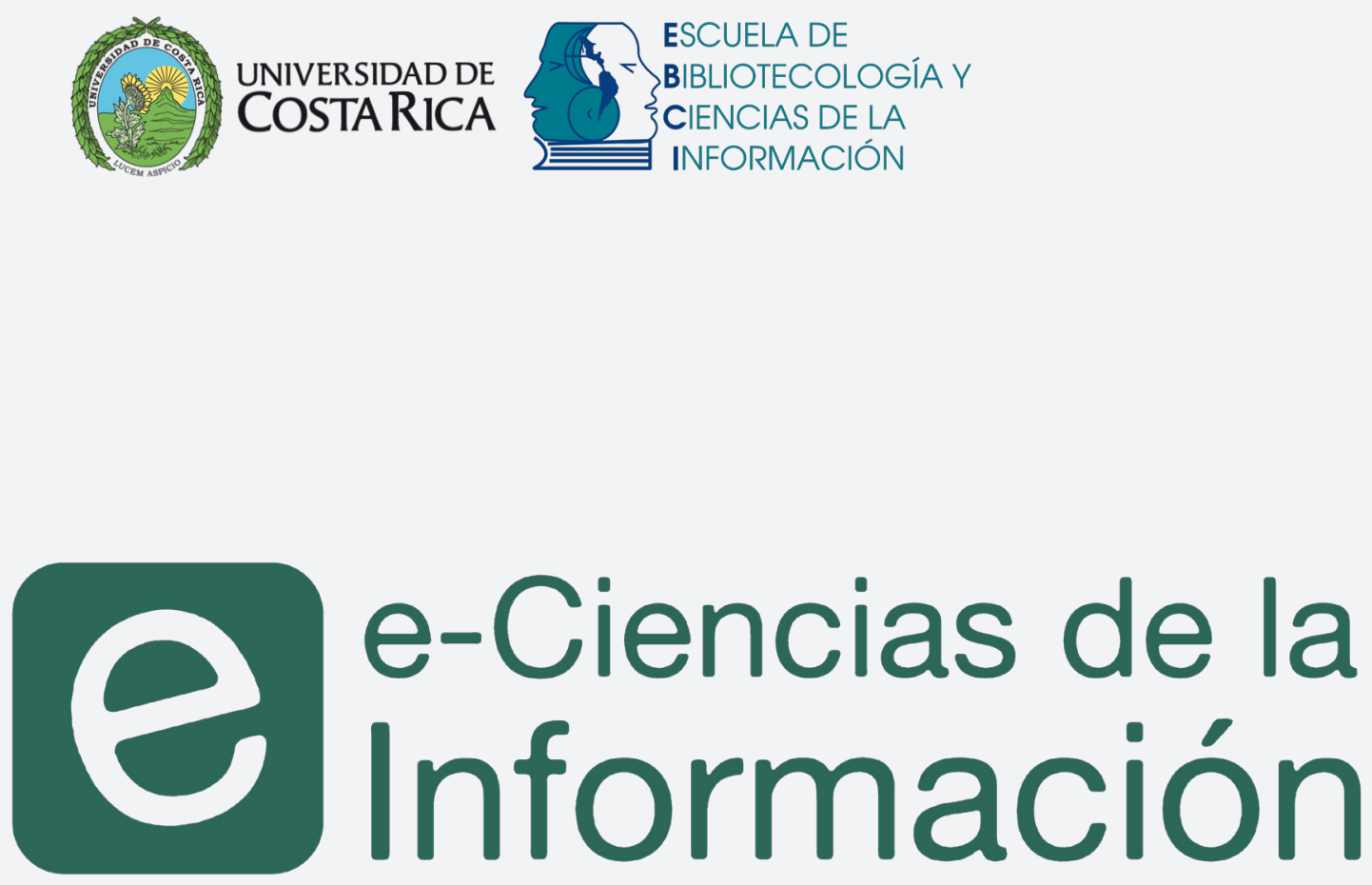

\title{
Cultura y sociedad: Próspero Calderón y su legado para las artes, letras y publicaciones costarricenses Jimena Sánchez Zumbado
}

DOI: https://doi.org/10.15517/eci.v8i1.29784

e-Ciencias de la Información, volumen 8, número 1, Ene-Jun 2017

ISSN: 1649-4142

\section{(ㄷ)(1)(5)(2)}

Universidad de Costa Rica

Escuela de Bibliotecología y Ciencias de la Información

revista.ebci@ucr.ac.cr | http://revistaebci.ucr.ac.cr 


\title{
Cultura y sociedad: Próspero Calderón y su legado para las artes, letras y publicaciones costarricenses
}

\author{
Culture and society: Prospero Calderón and his legacy for Costa \\ Rican arts, letters and publications
}

Jimena Sánchez Zumbado

\section{RESUMEN}

Próspero Calderón (1862-1934) será el primer costarricense que se dedique a la profesión de editor; asimismo, será fotógrafo, docente, diseñador y precursor de las Artes gráficas en el país. Bajo sus ideales de promoción de la cultura se fundan las primeras publicaciones costarricenses en formato de revista: Costa Rica Ilustrada y Páginas Ilustradas, presentando en sus páginas fotografías de H.N. Rudd, Manuel Gómez Miralles y Amando Céspedes, entre otros, así como textos de Joaquín García Monge, Justo A. Facio, Carmen Lyra y Lisímaco Chavarría. Su aporte es imprescindible en el estudio de la sociedad y del arte costarricense en la transición del s. XIX al s. XX. Por lo anterior, para la realización de esta investigación, se recurrió a la Metodología Histórica, desarrollada a partir de las etapas heurística y hermenéutica, para finalizar con una propuesta teórica bajo la figura de Biografía histórica.

Palabras Clave: Próspero Calderón; fotografía; Artes Gráficas; editor; Costa Rica Ilustrada; Páginas Ilustradas; revistas costarricenses; modernismo.

\section{ABSTRACT}

Prospero Calderón (1862-1934) will be the first Costa Rican to devote himself to the profession of editor; Likewise he will be photographer, teacher, designer and precursor of the graphic arts in the country. Under its ideals for the promotion of culture, the first Costa Rican publications are published in a magazine format: Costa Rica llustrada and Páginas llustradas, featuring on its pages photographs of H.N. Rudd, Manuel Gómez Miralles and Amando Céspedes, among others, as well as texts by Joaquín García Monje, Justo A. Facio, Carmen Lyra and Lisímaco Chavarría. His contribution is essential in the study of Costa Rican society and art in the transition of the s. XIX to s. XX.

In order to carry out this research, was used the Historical Methodology, developed from the heuristic and hermeneutic stages, to conclude with a theoretical proposal under the figure of Historical Biography.

Keywords: Próspero Calderón; photograph; Graphic art; editor; Costa Rica Ilustrada; Páginas llustradas; Costarican magazines; art nouveau.

1Universidad de Costa Rica. Escuela de Artes Plásticas. https://orcid.org/0000-0002-2223-2609. jimena. sanchez@ucr.ac.cr 
El final del s.XIX y el inicio del s.XX plantean una Costa Rica con grandes cambios culturales, educativos y sociales. El liberalismo está en pleno auge, el Estado crea instituciones educativas laicas, como el Liceo de Costa Rica (1887), el Instituto de Alajuela (1887) y el Colegio Superior de Señoritas (1888); las reformas estatales refuerzan las libertades económicas y políticas, creándose importantes instituciones dentro del aparato burocrático y relacionadas con la cultura, como el Archivo Nacional (1881), la Biblioteca Nacional (1890) o la Escuela Nacional de Bellas Artes (1897). También, nacen espacios públicos para responder a las nuevas necesidades y pretensiones, como el Teatro Nacional (1897) y el Teatro de Variedades (1891).

Desde Bélgica, referente para las corrientes modernistas especialmente en el campo de la arquitectura, se importan estructuras arquitectónicas en metal para ensamblar, como el Edificio Metálico (1896), o las hermosas gradas de hierro que adornan el edificio del Colegio Superior de Señoritas (1892), diseñadas por el ingeniero costarricense Lesmes Jiménez.

De igual manera, la literatura es una de las manifestaciones artísticas que más se proyecta en esta época, naciendo numerosas revistas de diversa índole en todo el mundo, debido a los nuevos paradigmas sociales y culturales e impulsada por los avances tecnológicos en lo que a producción de textos e imágenes impresas se refiere. Sirviéndose para sus propósitos, estas publicaciones se imprimen tanto en las clásicas imprentas manuales como en las accionadas por vapor o electricidad, con los tradicionales tipos móviles de madera y metal, o, mediante la naciente técnica de la impresión por linotipia que aportaría un cambio significativo en cuanto a la calidad y a la precisión de la impresión, así como una reducción en el tiempo para producir los ejemplares.

En el tema de las letras y la estética gráfica para Centroamérica y para Latinoamérica en general, la referencia será Francia y su Art Nouveau, representada en motivos y líneas vegetales. Las páginas de las revistas de entonces utilizarán tipografías orgánicas, dibujos y fotografías de gráciles modelos femeninas.

En Costa Rica nacen las primeras publicaciones periódicas de índole científico como: Anales del Museo Nacional de la República de Costa Rica (1887) editada por Anastasio Alfaro y de amplia difusión en museos y academias de todo el mundo, o con enfoque cultural tales como la Revista de Costa Rica (18901892), Pandemonium (1902-1914, 1913-1905) dirigida por J. Arrillaga Roqué en su primera época, y Justo A. Facio en su segunda época, Páginas Ilustradas (1904-1908) y Costa Rica llustrada (1887-1888, 1890-1892), estas dos últimas editadas y producidas por Próspero Calderón.

Calderón fue, en gran medida, el impulsor de distintas manifestaciones culturales, y muy especialmente del desarrollo de las nacientes profesiones de artista gráfico y de editor, no solo en Costa Rica, sino, también, en buena parte de Centroamérica. Al transcurrir el s.XX, su figura fue diluyéndose poco a poco, pero su obra -manifestada y recopilada por múltiples formas- sigue teniendo gran importancia en el estudio del modernismo y en el origen de la producción gráfica en el istmo centroamericano. 
Dado lo anterior, se propone como objetivo general de esta investigación demostrar y rescatar la importancia de la figura de Próspero Calderón Hernández como actor fundamental en el desarrollo cultural costarricense de finales del s.XIX y principios del s.XX, especialmente por medio de sus revistas Páginas Ilustradas y Costa Rica llustrada, sin dejar de lado sus otras contribuciones a la sociedad por medio del arte y la docencia.

\section{METODOLOGÍA}

El diseño metodológico para esta investigación se realizó a partir de la Metodología Histórica, ${ }^{2}$ así como de sus etapas heurística y hermenéutica. Para Fusco (2009), la Investigación Histórica

...tiene carácter científico, porque para conocer su objeto de estudio lo realiza a través de reglas y procedimientos propios del método científico; es una disciplina Humanista ya que los historiadores analizan y registran los acontecimientos individuales y grupales de la sociedad, el papel que los individuos desempeñan en las instituciones y fundamentalmente el significado de los acontecimientos en el contexto donde surgieron. (2009, p. 233)

La Etapa heurística se realizó en dos partes. En la primera, que duró aproximadamente siete años, se realizó la búsqueda de datos mediante fuentes documentales primarias (actas de nacimiento, de bautizo, cuadernos de clase, fotografías, entre otros) y secundarias (libros, revistas, manuales, informes oficiales, decretos etc.), es decir, se reprodujo y archivó todo material que pudiese relacionarse de una $u$ otra forma con el sujeto a estudiar; esta búsqueda se dio, especialmente, en los acervos del Archivo Nacional de Costa Rica, la Biblioteca Nacional Miguel Obregón Lizano, el Museo del Colegio Superior de Señoritas y la Biblioteca de la Asamblea Legislativa.

En la segunda parte se organizó todo el material recopilado por medio de una línea del tiempo en la que se enlazaron la vida y los hechos de Calderón junto con la síntesis histórica de la época, produciendo un guion cronológico, validado hasta donde fue posible, mediante la referencia cruzada entre fuentes primarias y secundarias.

Posteriormente, en la Etapa hermenéutica y a la luz de etapa dicha, se realizaron el análisis y la reflexión sobre la figura y los hechos asociados a Calderón, para concluir con la redacción del presente artículo en formato de Biografía histórica.

En ese sentido, la escogencia de la Biografía histórica, como medio para unificar y publicar los resultados de esta investigación, se origina en la premisa de la importancia del estudio sobre la vida y obra de los hombres y las mujeres que determinaron nuevos caminos hacia el avance de la educación y la cultura de los países centroamericanos en su tránsito del s.XIX al s.XX.

Al respecto, según Bazant (2013), el investigar sobre rasgos biográficos

En su forma más completa, sobre todo si se trata de un personaje del pasado, explica también sus actos como un arreglo al contexto social, 
cultural y político de la época, intentando reconstruir de manera documental su pensamiento y figura. (Bazant, 2013, p. 19)

También, Escobar Ohmstede (2015) opina que el aporte biográfico "no sólo provee información en esencia subjetiva sobre la vida entera de una persona, sino que incluye su relación sobre su realidad social, los contextos, las costumbres y las situaciones en las que el sujeto participó" (p. 1373).

\title{
3. PRÓSPERO CALDERÓN: DIBUJANTE, PROFESOR, EDITOR
}

\author{
La cultura es la memoria del pueblo, \\ la conciencia colectiva de la continuidad histórica, \\ el modo de pensar y de vivir. \\ Milan Kundera
}

La búsqueda genealógica, realizada como parte de esta investigación, ubica el nacimiento de Próspero Emeterio Calderón el 2 de marzo de 1863 en la ciudad de Cartago, ${ }^{3}$ hijo primogénito del matrimonio entre Francisco Calderón Núñez, de profesión artesano, y de Guillerma Rafaela Hernández Brenes, ama de casa. ${ }^{4}$ Este primer dato sobre el progenitor de Calderón inicia con una particularidad: su profesión.

Desde la época de la conquista y hasta comienzos del siglo XX, lo más común para los varones era dedicarse a la vida de campo, ya sea como jornalero, capataz o patrón (Pérez, 2010). Los pocos que ejercían otras profesiones, como los artesanos, y los aún menos frecuentes profesionales liberales, ocupaban un lugar particular en la sociedad, así como la posibilidad de tener avances económicos sustanciales, en relación con el resto de la población; por esto, aunque no se detalla a qué se dedicaba específicamente el padre de Calderón, -pues pudo ser sastre, alfarero, herrero, etc.-, sugiere un hogar donde se acostumbraban labores de creación, y donde la práctica constante de un trabajo se vería como el medio para dominarla y destacarse con ella (ver Figura 1).

\footnotetext{
3 Sobre el origen de Calderón ha habido cierta confusión. Distintas fuentes lo han citado como nativo de San José o incluso de Colombia, pues él mismo lo declara así, debido a que en cierto momento tuvo un desacuerdo con el Gobierno costarricense, por lo que decide trasladarse a vivir a Panamá - todavía perteneciente a Colombia- y declararse como colombiano, aunque finalmente y hasta el final de sus días residiría en Costa Rica.

4 Libro de Bautizos de 1863 -folio 84, número 103-y el Libro de Matrimonio de 1862, p. 296, de la Parroquia de El Carmen de Cartago.
} 
FIGURA 1

Retrato de Próspero Calderón Hernández. Aprox. 1900-1910, Fotógrafo desconocido.

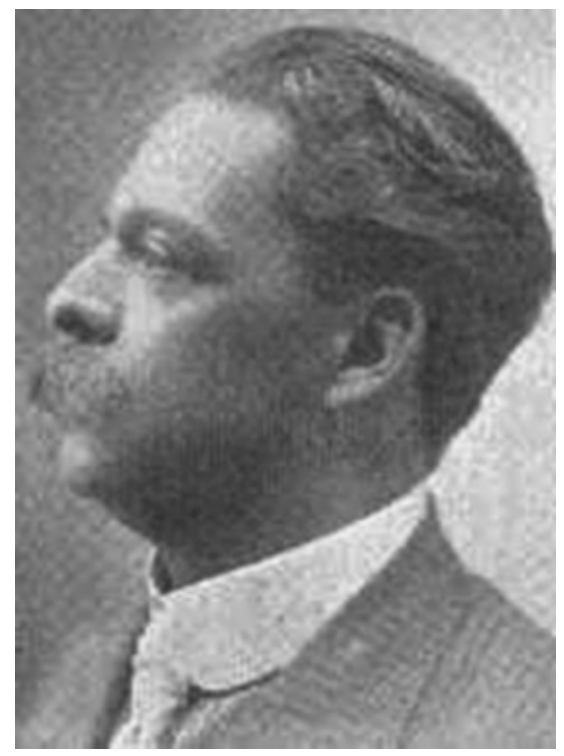

Fuente: Reproducción en el archivo personal de la investigadora.

Tal vez por motivos laborales, los Calderón Hernández y su prole se trasladan de su originaria Cartago hacia San José, teniendo certeza de esto a partir de 1874 , cuando se registra el nacimiento de la primera hija del matrimonio ${ }^{5}$ en la provincia de San José.

Es de suponer que la llegada a la capital le diera a la familia Calderón Hernández nuevas posibilidades para su desarrollo, sobre todo en el campo académico, pues prontamente Próspero -ya de 11 años de edad-inicia, en compañía de su hermano Francisco Calderón, estudios en la Escuela Pública Principal Primaria, ubicada en San José en lo que hoy es la plazoleta Juan Mora Fernández frente al Teatro Nacional, dirigida por José Chepito Céspedes, notable maestro de la época.

Concluida la primaria, iniciaría la formación secundaria en el Instituto Nacional, fundado en 1874, antecesor directo del futuro Liceo de Costa Rica y primer centro de enseñanza secundaria público y seglar del país, dirigido por el pedagogo canario Valeriano Fernández Ferraz (1831-1925); en una colaboración para Páginas Ilustradas, en la edición del año 8, no. 274, en 1911, que realiza desde Panamá y publicada el 12 de marzo de 1911, Calderón anotará que en 1879 era alumno de dicho Instituto.

Esta posibilidad de acercarse no solo a la educación primaria -que para la época era de difícil acceso, de muy regular calidad y la única que gratuitamente ofrecía el Estado- y aún más cursar la secundaria, determinó la visión de mundo del joven Calderón, pues a diferencia de muchos de sus compañeros de estudios, no procedía de la elite josefina.

En esta Institución se rozaría con los intelectuales más destacados del país,

5 María Francisca Gregoria Adela Calderón, bautizada en El Carmen, San José, el 18-11-1874; hija legítima de Francisco Calderón y Guillerma Hernández. 
ya que la mayor parte de sus profesores laboraban al mismo tiempo en el Instituto y en la Universidad de Santo Tomás. De la misma forma tendría contacto con los profesores europeos traídos por el Estado con el fin expreso de enseñar nuevas materias, como por ejemplo, el profesor José de Torres y Bonet, encargado de las lecciones de Química y Física, y que en la mayoría de los casos serían los fundadores de sus respectivos saberes en Costa Rica. La importancia de esta diversidad de conocimientos a los que tuvo acceso en el Instituto es, sin lugar a dudas, un germen que fructificará al momento de crear su diversa obra profesional.

Poco tiempo después y ya con 26 años de edad, el 15 de setiembre de 1888, Próspero se casa en la iglesia de La Merced en San José, con la joven Josefina Argüello Valverde, declarándose en el acta de matrimonio "de profesión dibujante". 6

La declaración de definirse a sí mismo como "dibujante" es interesante, pues aunque no hay fuentes que se refieran a esta parte de su vida, fue probablemente mediante "clases particulares" con algunos de los pocos maestros de la época que desarrolló sus habilidades, ya que la Escuela Nacional de Bellas Artes, primera institución estatal en dictar lecciones en esta materia, no sería fundada hasta 1897.

Lo que sí es seguro es que los primeros acercamientos al dibujo de Calderón se dieron durante su época de estudiante del Instituto Nacional, aunque parece ser que las lecciones de Dibujo eran muy limitadas, según una nota de prensa publicada en 1956 sobre el pintor Ezequiel Jiménez -alumno de dicho instituto y compañero de Calderón- citada por Eugenia Zavaleta (2002), en la que el mismo Jiménez relata que

En mis mocedades, valga decir mis tiempos de escolar, y mientras cursaba la primaria, no había en las escuelas asignatura especial de dibujo ni de música, como hoy existe. En aquella década primera del 70 todo era ocasional. En la secundaria tuve los primeros profesores de dibujo y de música. Más, también resultaron ser ocasionales. Hacían monigotes porque estaban urgidos de dinero. No porque supieran enseñar ni tuvieran vocación verdadera. (Zavaleta Ochoa, 2002, p. 2)

Aun así, el Instituto impartía dentro de su currículo lecciones de Dibujo natural, Dibujo lineal, Dibujo y elevado de planos y Dibujo topográfico y como asignaturas especiales ofrecía Dibujo de figura, adorno y de paisaje y Dibujo: estudios al crayón; algunos de estos cursos eran impartidos por el hábil y respetado dibujante inglés Enrique Etheridge, por lo que podría considerarse que la opinión de Enrique Echandi sobre la dudosa calidad de sus maestros, debe de tomarse en cuenta aunque no al pie de la letra.

Puede imaginarse la dificultad de un profesor de dibujo de finales del s.XIX para lograr un desarrollo homogéneo de las habilidades entre jóvenes de muy variados intereses y destrezas, así como las limitantes en cuanto a la variedad y calidad de los materiales; también, durante las lecciones de estos años, Calderón tendría la oportunidad de conocer y reproducir las famosas láminas francesas del Método Julien,? que el Instituto Nacional había comprado al maestro Etheridge, y que eran utilizadas por las más importantes academias

6 Libro de Matrimonios de 1888, folios 183 y 184, número 54, de la Parroquia de La Merced, San José.

7 Para más información sobre el tema de las litografías del Método Julien, se recomienda la lectura del artículo Las láminas de Dibujo de la Escuela Nacional de Bellas Artes (Sánchez Zumabado, 2013), publicado en la Revista Humanidades de la UCR. 
de arte tanto de Europa como de América.

La siguiente referencia cronológica, que relaciona a Calderón con el campo de las artes, es cuando con solamente 23 años de edad obtiene una medalla en la Primera Exposición Nacional, inaugurada el 15 de septiembre de 1886. La obra ganadora llevaría por título: "Melancolía", galardonada junto a piezas de los también dibujantes Fernando Zamora, quien sería fotógrafo y compañero en distintas empresas de Calderón, y Antolín Chinchilla otro pionero de la gráfica costarricense, entre otros.

Esta muestra, donde se presentaron arte plástico, piezas precolombinas, orquídeas y hasta colecciones de insectos, entre muchas cosas más, fue concebida como una antesala a la asistencia por parte del país a la Exposición Universal de París de 1889, por lo que encierra, en sí misma, una importante evidencia sobre el medio cultural y académico en la Costa Rica de finales del s.XIX.

\subsection{Costa Rica Ilustrada}

Al año siguiente, en 1887 y con apenas un cuarto de siglo de vida, Calderón dará lo que se podría llamar un "salto al vacío", pues sin ningún otro referente nacional sobre el que apoyarse, fundará la revista modernista Costa Rica Ilustrada, revista quincenal de Ciencias, Arte y Literatura, fungiendo como editor y propietario junto a José Antonio Soto, quien al igual que Calderón fue dibujante y grabador.

El primer número salió al público el 12 de junio de 1887, su valor fue de un valor de 0,15 centavos de peso el número suelto y era posible realizar hacer suscripciones tanto en el país como en el extranjero. Anteriormente, se había publicado una separata con fecha del 21 de mayo de 1887, donde lo noveles editores señalaron que

la parte artística será desempeñada por nosotros mismos y para llenar los tres pliegos de que por ahora constará el periódico, los grabados ocuparán la mitad de uno por lo menos; pliego y medio sino más estará consagrado al texto; dedicaremos una parte a reproducir alguna novela escogida de mucho mérito; para que el comercio encuentre también en él un órgano de publicidad, dejaremos lo restante para anuncios; y nos prometemos ampliar en breve la parte artística con selectas piezas de música. (Calderón Hernández y Soto, 1897, p. 1) 
FIGURA 2

Portada de la separata de presentación del primer número de Costa Rica llustrada.

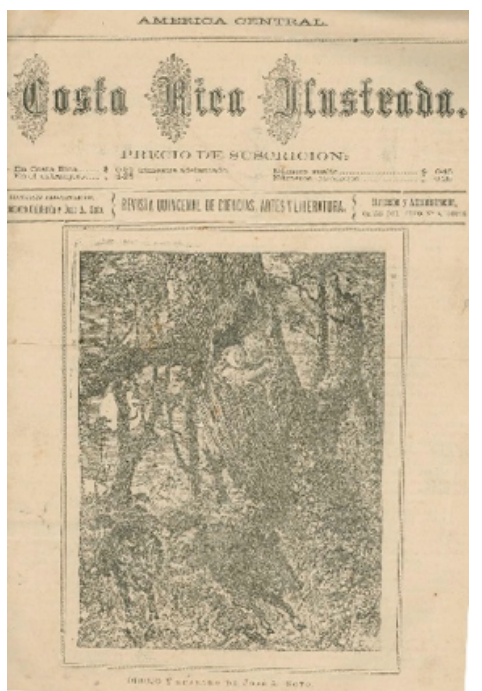

Fuente: Calderón Hernández (1887).

FIGURA 3

Portada del primer número de Costa Rica Ilustrada.

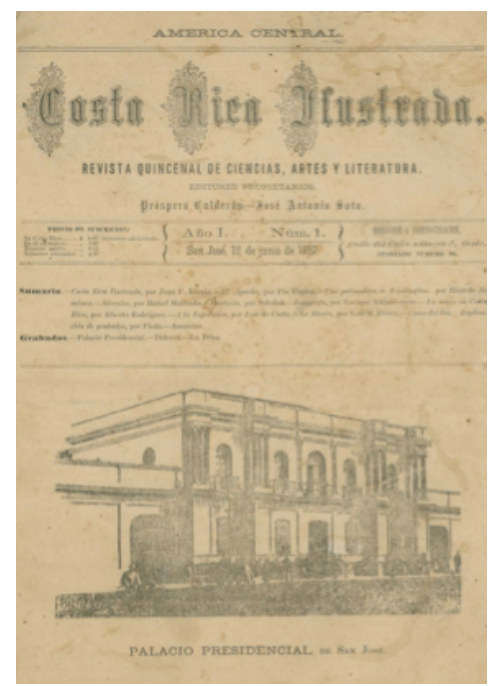

Fuente: Calderón Hernández (1887).

En esta separata de presentación o prospecto -que posee una portada y dos planas- presenta, como bien habían indicado los editores, un dibujo y grabado de José Antonio Soto (ver Figuras 1 y 3 ).

El número inicial es presentado por el profesor Juan Fernández Ferráz, ${ }_{1}^{8}$ quien expresa que

8 Juan Fernández Ferráz (1849 Canarias, España - 1904 San José, Costa Rica) destacado intelectual y educador de la época, quien invitado por su hermano V. Fernández, encargado de la reforma educativa de Mauro Fernández, migra a Costa Rica. 
Un periódico ilustrado, una revista de artes ciencias y letras, es indudablemente un cuadro que representa al vivo estado social del pueblo donde sale a la luz; más todavía, la prensa toda de un país retrata a su gente, es a su modo una ilustración, un grabado exacto, casi una fotografía. $(1887$, p. 2$)$

Luego de discursar sobre la relación de la patria y las empresas del hombre, concluye diciendo: "Artistas de 'Costa Rica llustrada' escritores costarricenses, juventud estudiosa: preparad los pinceles y la pluma. El lienzo y el papel están listos" (p. 3), es decir, invita a los costarricenses a colaborar con textos para publicar.

En sus términos, la portada del primer número muestra un grabado en metal - de regular calidad técnica y claramente tomado de una fotografía- que representa el Palacio Presidencial de San José. Los colaboradores para este primer número serán reconocidos intelectuales, como: Juan F. Ferráz, Pío Víquez, Justo Facio, Ricardo Jiménez y Rafael Machado, entre otros.

Con este número de Costa Rica Ilustrada se comienza la producción y la publicación de revistas en el país, pues aunque ya circulaban con relativa frecuencia ejemplares en este formato de publicación periódica eran de origen extranjero y llegaban a la elite por medio de suscripciones, además de que por las dificultades del correo de la época arribaban al país desfasadas en relación con su periodicidad.

Es posible dilucidar a partir de las distintas presentaciones y de los textos seleccionados para publicar, que el verdadero énfasis de esta revista no estaba solo en la creación de una revista literaria costarricense propiamente dicha, sino que buscaba inculcar los paradigmas culturales europeos de la época: el modernismo se refleja en sus páginas, mediante la estética literaria y la gráfica, aunque de una forma mucho menos intensa que en sus países de origen.

Este número, además, contiene una importante particularidad que merece ser mencionada y registrada: dedica tres planas a la publicación de un artículo de Alberto Rodríguez, llamado La mujer en Costa Rica y fechado en San José en 1887, donde se diserta de forma novedosa sobre la importancia de la educación de la mujer costarricense.

La discusión sobre este tema se observa como innovadora, porque a diferencia de muchos de los artículos publicados en adelante en el país, en especial luego de la Reforma educativa emprendida por Mauro Fernández, que tendría como uno de sus mayores logros la fundación en 1888 del Colegio Superior de Señoritas e iniciaría la lucha por el sufragio femenino en Costa Rica, este texto no habla únicamente de la necesidad de educar a la mujer en pos de lograr una buena esposa y madre, es decir, no como sujeto, sino como un objeto de influencia sobre los varones que la rodearían a lo largo de su vida que era la posición común de los que defendía la importancia del tema, sino que encima defiende la tesis de una igualdad de inteligencia y derechos para ambos sexos. Es de valorarse no solo la posición del autor del texto, sino también la de los noveles editores, pues proponen la reflexión sobre un tema tan difícil para su momento, tomando posición, además, al publicarlo con valentía en su primer número, lo que pudo -hipotéticamente hablandohaber producido un ambiente difícil para lograr la aceptación de la revista, cosa que por suerte no sucedió. 
En lo concerniente a la parte técnica de la publicación se imprimirá en la Imprenta Nacional por cuenta del Tesoro público. ${ }^{9}$ Con gran probabilidad, Calderón debió aprender el oficio de las artes gráficas como asistente en alguno de los talleres de imprenta que existían en San José, ${ }^{10}$ o, incluso en la misma Imprenta Nacional, a la que de una u otra forma estuvo ligado toda su vida.

Mientras la revista continuaba publicándose, Calderón se plantea un nuevo reto: solicita en 1890 al presidente José Rodríguez Zeledón, a quien parece había apoyado activamente durante su candidatura presidencial, la posibilidad de impartir lecciones de Dibujo, por lo que el mandatario, en una de sus primeras decisiones en el cargo y a través la Secretaría de Instrucción Pública, crea las clases de Dibujo para adultos de ambos sexos, según acuerdo no. 50 del 31 de mayo" nombrando a Calderón -de forma gratuita- como su profesor.

Las lecciones se impartirán en las instalaciones del Liceo de Costa Rica, y según el artículo $\mathrm{V}$ del acuerdo, versarán sobre Dibujo de ornamentación y adorno, Dibujo animal, Dibujo de figura humana y Dibujo de paisaje; tendrán horario diferenciado, es decir, se dictarán en días y horarios distintos para uno u otro sexo, y en horario nocturno, pues el edificio era ocupado en la mañana y tarde por las lecciones de secundaria. Los gastos y materiales serán proporcionados por el Gobierno, mientras que los útiles para impartir las clases serán los que posee el Liceo, ${ }^{12}$ y que serían piezas del Método Julien. ${ }^{13}$

Según el decreto, este curso debería finalizar anualmente con un concurso para determinar los tres mejores trabajos de los alumnos y tres de las alumnas, proponiendo el mismo decreto que las seis obras ganadoras serían adquiridas por el Estado y que serían el inicio del acervo para un futuro Museo Nacional de Pintura; sin embargo, Luis Ferrero Acosta (2014) menciona en Sociedad y Arte en la Costa Rica del s.XIX que esta decisión fue solo un ardid para, de momento, tranquilizar a quienes abogaban por un avance en las Artes Plásticas costarricenses, pues aunque las lecciones de dibujo se impartieron, dicho museo sería creado hasta casi 80 años después. De todas maneras, estas clases de Dibujo serán las primeras lecciones relacionadas con el arte y de carácter público que se impartirán en el país, en otras palabras, no como negocio, sino como un aporte del Estado al crecimiento cultural de la población.

Calderón, siempre visionario e interesado en la divulgación de la cultura, tenía un sueño todavía más ambicioso, el cual se deja ver en una columna publicada en periódico El Artesano de febrero de 1890 y firmada por Carlos Gagini bajo el título Proyecto, que a la letra dice

Mi amigo Próspero Calderón, el fundador de Costa Rica llustrada, el joven entusiasta que ha trabajado siempre con ardor por el progreso de las artes en nuestra patria, intenta fundar un periódico nuevo, titulado La llustración Centroamericana, de carácter exclusivamente científico-literario, en el que se publicarán grabados relativos

9 Se cita dirección y administración de la Revista en Calle del Cuño no. 5 oeste, San José.

10 Las técnicas de las artes gráficas, desde la llegada de la Imprenta al país, eran aprendidas por medio de la práctica, es decir, como aprendices en talleres, pues fue hasta el año de 1907 que la Congregación Salesiana creó formalmente una escuela de artes y oficios en Cartago para estos fines.

11 Este acuerdo se publicó en La Gaceta, no. 126, del 01 de junio de 1890.

12 Liceo de Costa Rica, primer colegio estatal para varones fundado en 1887 como parte de la reforma educativa de la administración Soto.

13 En la actualidad no se conserva ninguna de estas piezas, pero el mismo método fue importado en 1897 por la Escuela Nacional de Bellas Artes, y se encuentran en la Universidad de Gipłieaimente a asuntos de 
las Cinco Repúblicas, y artículos de los

más afamados literatos de éstas. (Gagini, 1890, p. 3)

A pesar del interés de Calderón, este plan deberá esperar todavía algunos años más, pero deja leer entre líneas que, con sus escasos 28 años, ya existía en él un interés por el crecimiento intelectual, laboral y artístico, tanto a nivel personal como social.

Probablemente, a partir de la primera experiencia como editor de Costa Rica llustrada y para poder hacer realidad su intención de crear una publicación centroamericana, Calderón se planteara la necesidad de realizar estudios formales en la técnica del fotograbado, indispensable para realizar publicaciones, máxime si gran parte del enfoque de la revista estaba en el atractivo de la imagen gráfica. Si ya poseía experiencia como dibujante y se dedicaba a ello de modo profesional, parte del camino estaba andado, lo siguiente sería aprender las técnicas de la reproducción múltiple de imágenes, pero en el país no había aprendizaje formal sobre el tema, salvo el que pudiese lograrse como aprendiz en el taller en alguna imprenta y con materiales escasos y de dudosa calidad, porque en esa época -y aún en la actualidad- la importación de materiales artísticos era muy difícil.

En todo caso, a finales del s.XIX, el fotograbado era la técnica más moderna para reproducir de forma múltiple dibujos y fotografías, siendo la más utilizada para imprimir las imágenes en publicaciones periódicas. El fotograbado, como su nombre lo indica, se presenta como una mezcla entre la técnica clásica del grabado en metal -donde se utilizan planchas de zinc, cobre u otros metales- y la técnica fotográfica -fotosensibilizando la plancha de metal-, para posteriormente "quemarla" por inmersiones en ácido (Martínez, 2001, pp. 248-256) para obtener una imagen que al entintarse puede reproducirse en papel por medio de una prensa para impresión.

En 1891, el gobierno otorga a Calderón la anhelada beca para estudiar fotograbado en Francia (Secretaría de Gobernación, Policía y Fomento, 1892). Sobre cómo se dan las relaciones de hechos alrededor de esta beca, el notable profesor y escritor costarricense Carlos Gagini, amigo personal de Calderón, lo relata así

En la misma época me encargué de la redacción de Costa Rica llustrada, importante revista literaria fundada por Próspero Calderón; y habiéndose empeñado éste en que le escribiera yo al Presidente para que le enviase a Europa a estudiar fotograbado, no vacilé en hacer el servicio a mi amigo, aunque yo no tenía relaciones con el Sr. Rodríguez, ${ }^{14}$ quien accedió a mi solicitud, y en consecuencia quedé yo al frente de la revista, ad honórem. (Gagini, 1961, p. 53). ${ }^{15}$

En la Memoria de la Secretaría de Gobernación, Policía y Fomento (Memoria, 1891), se consigna que la beca otorgada es en la rama del Grabado, y se da con el fin de preparar maestros para que en un futuro se dediquen a la enseñanza de las materias no comprendidas en los programas de educación. Por supuesto, Calderón debió de suspender las lecciones de Dibujo para adultos, y al no ser asumidas por otro profesor el proyecto murió.

\subsection{Costa Rica Ilustrada: revista de Ciencias, Artes y Literatura}

En una segunda época de 1890 a 1892 la antigua Costa Rica llustrada cambiará su nombre a Costa Rica llustrada: revista de Ciencias, Artes y Literatura, eliminando de su título la periodicidad quincenal, pues en la portada dirá ahora que se publica

14 El Presidente de la República al que se refiere Gagini es don José Joaquín Rodríguez Zeledón (1838 -1917), quien ejerció el cargo de 1890 a 1894.

15 Obra póstuma, pues su autor había fallecido en 1925. 
cada diez días, y presentará el mismo texto de introducción de Ferráz del volumen 1 de Páginas Ilustradas. Calderón continúa como director, y acompañándose en funciones de Redactores por Joaquín Pablo Vélez, Ramón M. Quesada, Vidal Quirós y Carlos Gagini; en algunos momentos, el director será Pío Víquez, y José Antonio Soto aparecerá como propietario. Asimismo, sus autores en ciertos números la describen como semanal, e incluso como periódico, aunque comprobadamente nunca perdió la estructura ni física ni conceptual de una revista.

A mitad del año 1891, cuando Calderón debió de haber partido a Europa, las portadas de la Revista consignan como director y editor a Carlos Gagini, en quien Calderón confiaba plenamente, y en funciones de administrador se cita primero al hermano de su esposa, Marcelino Argüello y después a Francisco Calderón, su propio hermano.

A pesar de que Próspero está en París, con alguna frecuencia actúa como corresponsal extranjero para su propia revista, de la que nunca se desligó por completo. Por ejemplo, en la publicación del 4 de diciembre de 1891 (de la edición de la época 2, año 2, no. 2), envía un fotograbado suyo que ilustra una nota sobre el suicidio del General Boulanger, militar de gran renombre en su época, y cuya muerte llenó de texto e imágenes las revistas francesas y de otros países, pues además el hecho tenía un trasfondo pasional. Calderón comunica que la imagen fue tomada del Journal Illustre. En la esquina inferior derecha puede leerse "H. Meyer" y en la inferior izquierda "P. Calderón". Henry Meyer será uno de los ilustradores más publicados por las revistas francesas de la época, por lo que es de gran importancia que Calderón tenga oportunidad de fotograbar sus estampas (ver Figura 4).

FIGURA 4

Suicidio del General Boulanger del Journal Illustre, París, 4 de diciembre de 1891. Dibujo de H. Meyer. Fotograbado por Próspero Calderón

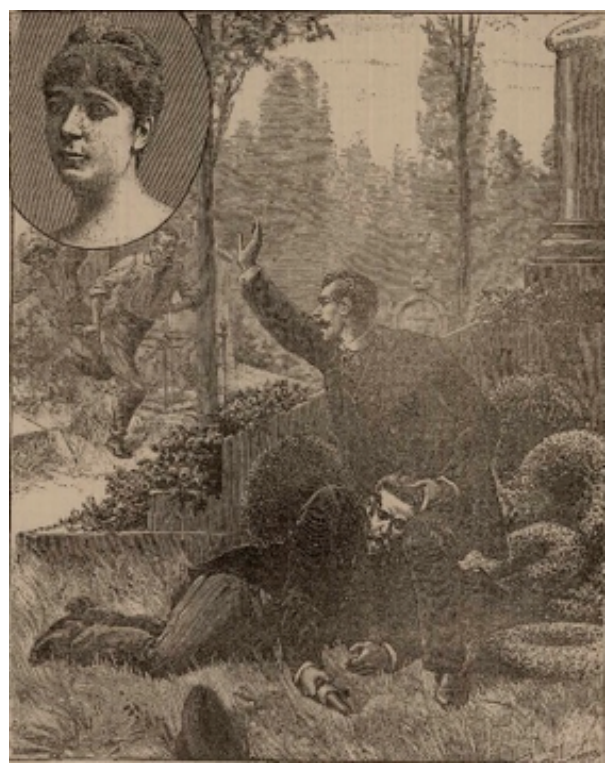

Fuente: Archivo personal de la investigadora.

En 1892, estando Calderón todavía en Europa, Costa Rica Ilustrada sale repentinamente de circulación, en palabras de Gagini, al publicarse una poesía del poeta mexicano Salvador Díaz Mirón, ${ }^{16}$ el Presidente Rodríguez 
cierra la revista, pues considera que la intención del poema es subversivo. Al mismo tiempo, tanto Gagini como Calderón serían contemporáneos y colegas de la reconocida Generación del Olimpo, pero no compartirían sus posiciones oligarcas y elitistas, siendo más bien precursores, especialmente Gagini, de las nuevas tendencias costumbristas, lo que puede notarse en el cambio que poco a poco empezaba a verse en los textos publicados.

El mismo Calderón opinará años más tarde que esta revista, en su primera época, no consiguió llenar por completo sus expectativas, especialmente en la parte artística, aunque reconoce que obtuvo de forma abundante el favor del público costarricense. ${ }^{17}$

Es de suponer que, al terminar sus estudios en Europa, ver cerrada su revista y no contar con un ambiente político ni económico en su favor, deberá buscar $\mathrm{u}$ otra forma de sustento $\mathrm{u}$ otro lugar para poder continuar ejerciendo su profesión. Calderón hará lo segundo: buscará nuevos horizontes.

\subsection{Próspero Calderón y el primer taller de fotograbado en la}

\section{Escuela Nacional de Bellas Artes de Guatemala}

No se tienen noticias de cómo Calderón decidió viajar a Guatemala, ni cómo llegó a relacionarse con la Academia guatemalteca, es probable que algún contacto logrado en Europa, o conseguido por medio del intercambio cultural de Costa Rica llustrada diera el enlace con el vecino país; lo cierto es que para finales de 1892 ya se hallaba instalado junto a su familia en la capital guatemalteca. $^{18}$

A finales del s.XIX, la República de Guatemala se hallaba, al igual que Costa Rica, en medio de una reforma educativa impulsada por el contacto con las ideas europeas y las corrientes liberales. El Presidente guatemalteco de la época, José María Reyna Barrios (1854-1898), había organizado el 21 de marzo de 1893 en la Universidad Nacional distintas facultades que se habían fundado anteriormente y que tenían funcionamiento independiente, siendo esta sucesora de la antigua Real y Pontificia Universidad de San Carlos Borromeo. Una de las instituciones recién fundadas sería la Escuela de Bellas Artes, bajo el Decreto ejecutivo del 10 de mayo de 1892. ${ }^{19}$

El Artículo no. 2 de este acuerdo dice textualmente: "El Instituto constará por ahora de las Escuelas siguientes: De Dibujo y Grabado. De Pintura. De Arquitectura" (Recopilación de las Leyes, 2010, p. 32). Mientras tanto, en el apartado correspondiente a la Escuela de Grabado, artículo 11 dice: "En la Escuela de Grabado se enseñarán las materias siguientes: Grabado en madera en todas sus partes. Grabado en acero. Retratos. Vistas. Pasados. Facsímiles. Preparación de maderas. Tiro de pruebas. Mapas, Letras. Heliografía. Galvanoplastía" (Recopilación de las Leyes, 2010, p. 33).

de Alejo Carpentier.

17 En la Introducción de Páginas Ilustradas (Año 1, no. 1, enero de 1904) pueden encontrarse reflexiones de Calderón sobre el tema (Calderón Hernández, 1887).

18 En la partida de nacimiento de su hija Josefina Emilia Calderón del 24 de febrero de 1893, Calderón declara que habita el "la casa número treinta y uno de la doce Calle Oriente" (FamilySearch.org, 2017; Guatemala Registro Civil, 1877-2008, entrada por Josefina Emilia Calderón Arguello, registro de nacimiento, p. 65, certificado 123, Archivo General de Centro America, Ciudad de Guatemala, microfilm de FamilySearch 129100).

19 Publicados en la Recopilación de las Leyes de la República de Guatemala 1892-1893, tomo XI, de 1894. 
Con fecha del 20 de junio de 1892 como otro acuerdo presidencial, complementando el del 10 de mayo se encuentra este interesantísimo dato que se transcribe tal como se publica en la Recopilación de leyes de la República de Guatemala de aquel año

Vista la solicitud presentada al Gobierno por Don Próspero Calderón; y: CONSIDERANDO Que es conveniente aprovechar sus aptitudes en beneficio público, fomentando el desarrollo de los elementos de cultura nacional, el Presidente ACUERDA

$1^{\circ}$ Fundar en la Escuela Nacional de Bellas Artes una sección de Fotograbado, á [sic] cargo del expresado señor Calderón, con la dotación mensual de cien pesos; comprometiéndose dicho señor á [sic] transmitir sus conocimientos en ese arte á [sic] los alumnos que se designe y cuyo número no podrá exceder treinta.

$2^{\circ}$ Fundar así mismo un periódico ilustrado cuya propiedad y administración corresponderán al mismo señor Calderón por el tiempo que dure su buen comportamiento, en la inteligencia de que esa publicación se dedicará preferentemente á [sic] dar á [sic] conocer el país en el exterior y difundir entre las clases populares la mayor suma de conocimientos útiles.

$3^{\circ}$ Autorizar el gasto de mil cuatrocientos ochenta francos que importarán los útiles que deben hacerse venir del extranjero para fundación del taller, y el que la suma que sea necesaria para su instalación: ambas partidas se tomarán de la señalada en el Presupuesto general para gastos extraordinarios de Instrucción Pública. (Recopilación de las Leyes, 2010, p. 75)

La Universidad Nacional de Guatemala cerraría sus puertas en 1897, debido al fuerte problema económico que enfrentaba el Gobierno. Tras el asesinato de Reyna Barrios se reabriría el establecimiento, y luego de distintas etapas pasaría a llamarse Universidad de San Carlos de Guatemala. En el Artículo $2^{\circ}$ citado se dice que se deberá: "Fundar así mismo un periódico ilustrado cuya propiedad y administración corresponderán al mismo señor Calderón".

Calderón Hernández fundaría entonces no un periódico, sino una revista al estilo de la que acababa de perder en Costa Rica y la titularía Guatemala Ilustrada Revista de Ciencias Artes y literatura Centro-Americanas [sic], cuyo primer número vería la luz el 15 de setiembre de 1892 y tendría periodicidad semanal. Siendo su editor y propietario, continuaría la misma línea de publicación: imágenes, poesía, crónicas teatrales y sociales, y además de los aportes de intelectuales guatemaltecos, internacionalizaría entre otros a Aquileo Echeverría, Carlos Gagini, Justo A. Facio, quienes seguirían colaborando desde Costa Rica en distintas secciones. La impresión de la publicación se realizaba en una imprenta privada, ya que el Gobierno de Guatemala se encontraba apenas importando de Europa un taller de fotograbado para esos menesteres y para fines pedagógicos, por lo que Calderón aclara en la presentación del primer número que mientras tanto utilizará fotograbados que él mismo había preparado "en otro tiempo" para Costa Rica llustrada. Ya para 1893 esta revista se imprimía y encuadernaba en los Talleres de Tipografía Nacional de Guatemala (ver Figura 5). 
FIGURA 5

Portada del Índice de 1892-1893 de Guatemala Ilustrada revista de Ciencias Artes y Literatura Centro Americanas

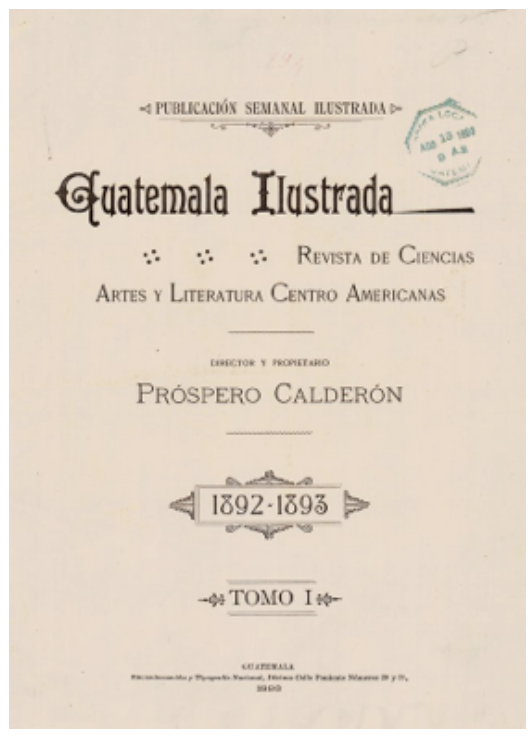

Fuente: Calderón Hernández (1892b).

En la primera página del prospecto de Guatemala Ilustrada, Calderón como director hace la siguiente reflexión, donde puede leerse un poco la desazón que le ha producido la razón del cierre forzado de su revista en Costa Rica

No obstante los progresos hechos por el periodismo centroamericano en los últimos años preciso es confesar que el arte no ha tenido entre esos órganos de publicidad sino escasísimos representantes. La política absorbe casi por completo la atención de nuestras Repúblicas al punto de mirar con desdeñosa indiferencia cualquier revista que prescindiendo de aquella y proponiendo fines meramente científicos, artísticos o literarios contribuye por otras vías a la educación popular. (Calderón Hernández, 1893, p. 1)

Igualmente, célebre en Guatemala como su hermana costarricense, esta revista se publicaría con regularidad durante los tres años que los Calderón Argüello permanecerían en ese país, contribuyendo al desarrollo de las letras, la gráfica y la cultura guatemalteca.

La creación de la Escuela Nacional de Bellas Artes de Costa Rica se daría hasta cinco años después que la de Guatemala, y para que se creara una carrera relacionada al grabado y la estampa, pasarían más de setenta años, lo que explica por qué Calderón, al llegar los difíciles cambios políticos que se vivían Guatemala, decide, en lugar de volver a su tierra natal, migrar de nuevo, en este caso a El Salvador, donde se le proporcionaría el ejercer de forma estable la profesión recién estudiada. 


\subsection{El Porvenir de Centro América y la Dirección de la Imprenta}

\section{Nacional de El Salvador}

Asentado en El Salvador desde el año de $1895,{ }^{20}$ Calderón cumplirá un viejo sueño: fundará la revista El Porvenir de Centro América, donde pretendía lograr una publicación aún más fuerte y con mayor presencia de escritores de la región Centroamericana. Solo se publicará de 1897 a 1898, irónicamente y a pesar de sus ilusiones, terminará siendo la menos célebre de sus empresas.

Al igual que en otras oportunidades, Calderón complementa su trabajo de director y editor con otro más estable para mantener a su numerosa descendencia; en este caso, desempeñará el cargo de Director de la Imprenta Nacional de El Salvador, aprovechando todo lo aprendido en los talleres de la Imprenta Nacional de Costa Rica. ${ }^{21}$

Poco después del cambio de siglo, ${ }^{22}$ Calderón dejará El Salvador y volverá a Costa Rica, trabajando en la primera y segunda decena del s.XX como profesor de Caligrafía y Dibujo en el Liceo de Costa Rica y en el Colegio Superior de Señoritas, siendo así miembro del grupo más prominente del país en el ámbito cultural, científico y educativo, y aprovechando esta experiencia para la publicación de distintos manuales sobre Caligrafía (ver Figura 6 y Figura 11).

\section{FIGURA 6}

Personal docente del Liceo de Costa Rica, año de 1907

Nota: En la fila de en medio, y primero de izquierda a derecha con bastón y sombrero en la mano, Próspero Calderón. Fotografia publicada a doble página.

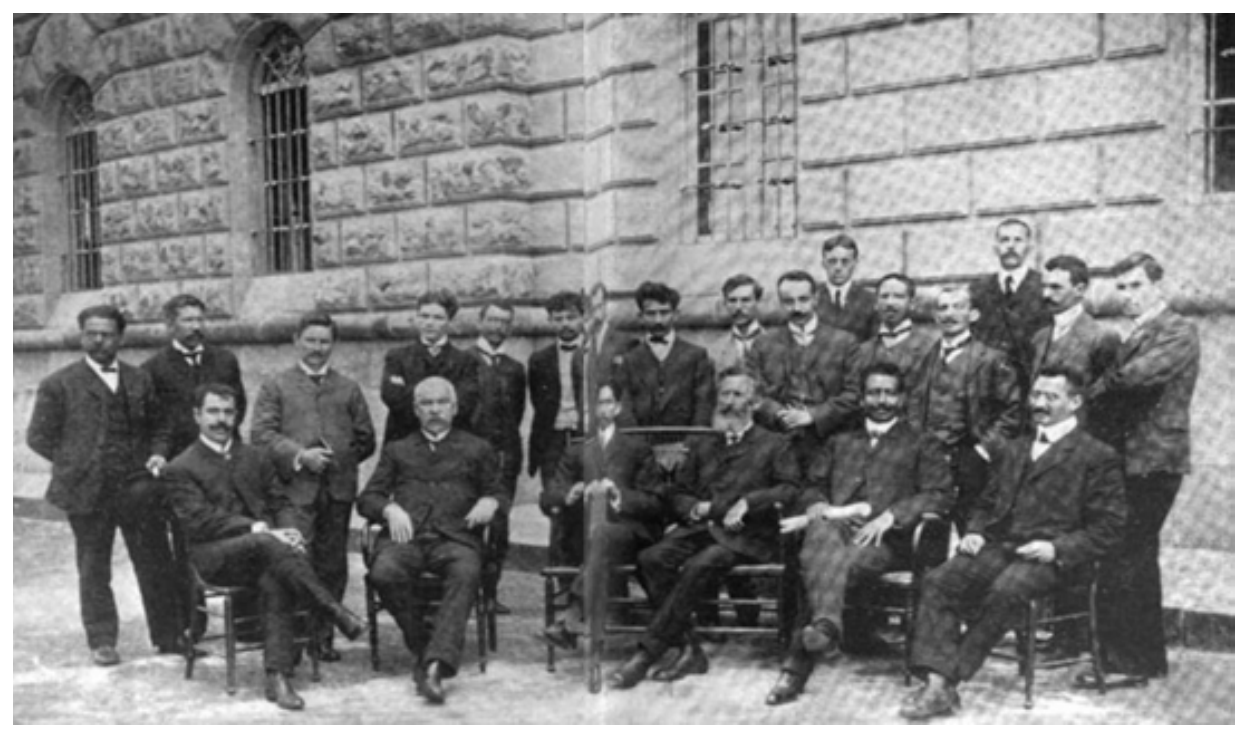

Fuente: Costa Rica llustrada, 1907, p. 2522.

20 De nuevo la referencia la da el Registro de nacimiento del 23 de setiembre de 1895, esta vez de su hijo Carlos Próspero Calderón nacido el 5 de setiembre de 1895 en San Salvador, El Salvador.

21 Llamada también en distintos momentos Tipografía Nacional.

22 Se encontró como última fecha en El Salvador, el Acta de bautizo de su hijo Guillermo Calderón correspondiente a junio de 1900, y luego en agosto de 1902, el nacimiento de su hija Lina Calderón en San José, Costa Rica. 


\subsection{Publicación de Vistas de Costa Rica}

En el año de 1901, Calderón presenta al público el álbum Vistas de Costa Rica, una de las primeras publicaciones de su estilo en Costa Rica, producida por un costarricense y realizada en su totalidad en el país. Con un tamaño de $81 / 2{ }^{\prime \prime} \mathrm{X}$ 11 "aproximadamente y de formato apaisado, muestra fotografías en blanco y negro de distintos paisajes del territorio nacional. Todas las fotografías fueron realizadas por Paynter Bros. y por Fernando Zamora, pero fotograbadas en su totalidad por el mismo Calderón (Calderón Hernández, 1901). La impresión, como se cita en la primera página, se produjo en las prensas del diario La República (ver Figura 7).

Las imágenes se presentan sin ningún guion o lógica espacial, simplemente están impresas sobre un título en idioma español que la describe con brevedad y en la siguiente línea traducido al inglés; careciendo de número de página y de cualquier otro detalle sobre el autor o la imagen -salvo las firmas que pueden notarse en la fotografía-, por lo que es posible encontrar, por ejemplo, una fotografía del Foyer del Teatro Nacional seguido de una imagen de tres hombres sobre el puente ferroviario del Río Reventazón.

Asimismo, la ausencia de números de página y coherencia temática hace suponer que Calderón fue seleccionando las fotografías hasta tener una cantidad suficiente para publicarlas; además, varias de estas imágenes circularon después como tarjetas postales independientes, muy común en la época que fuesen vendidas o incluso obsequiadas como cortesía a los clientes por parte de los dueños de establecimientos comerciales y hoteles.

El único texto que encabeza la obra corresponde a una plana está igualmente en español e inglés, y proporciona datos numéricos sobre distintos temas, como el valor monetario del Edificio Metálico y la cantidad de alumnos que asisten a sus aulas, el número de maestros que laboran en el país, el flujo de paquetes tramitados por la Oficina de correos, los distintos tipos de madera que se pueden encontrar, o la descripción de la población del país como de "300,000 blancos y sólo 2\% de aborígenes" (Calderón Hernández, 1901, p. 2). En fin, retrata a una Costa Rica en pleno auge industrial y plenamente correspondiente al imaginario de la Suiza Centroamericana.

De las 38 imágenes, 21 pertenecen a la provincia de San José, 13 a la zona atlántica, 2 a Puntarenas y 1 a Sabanilla de Alajuela. Hay, además, otra imagen la que, según la descripción, pertenece a un paseo de alumnos y profesores del Liceo de Costa Rica, donde Calderón está dentro de la multitud.

Como detalle, esta publicación es de las primeras en exhibir imágenes del desarrollo de las plantaciones de bananeras de la zona atlántica, así como de trabajadores afrodescendientes de la empresa Northern Railway Co. ${ }^{23}$

Elaborado con una clara visión comercial, Calderón promocionaba su libro no solo entre la elite económica y social costarricense, sino, también, como una obra digna de ofrecerse a visitantes y a representantes políticos extranjeros, por eso, no es de extrañar que señale que el país posee templos católicos y protestantes, pues la visita y migración de no católicos europeos era cotidiana -dentro de lo que se puede decir para la época-, especialmente en San José.

23 Compañía ligada en el país a la explotación de cultivos bananeros y la creación de ramales ferroviarios, especialmente en la zona Caribe. 
FIGURA 7

Primera página de Vistas de Costa Rica. Dedicado y autografiado por Próspero Calderón.

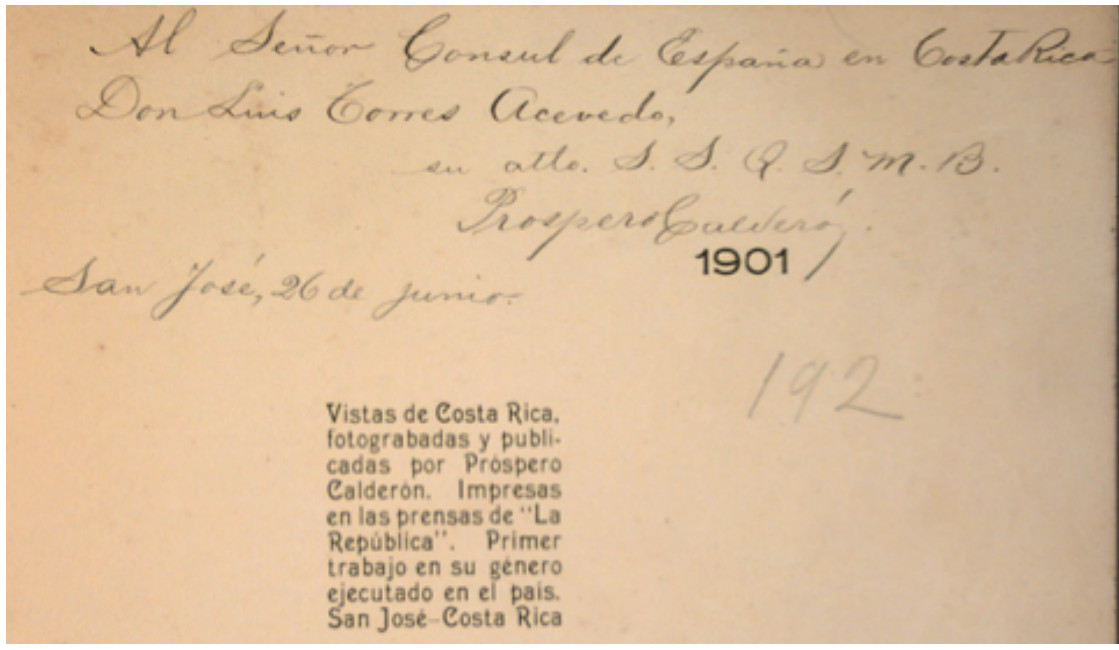

Fuente: Calderón Hernández (1901, p. 1)

En la actualidad, considerada un clásico tanto en el tema relacionado a fotografías antiguas como en lo correspondiente a los primeros impresos nacionales, esta publicación es inmensamente difícil de encontrar, conociéndose pocos ejemplares originales; por suerte, el Sistema Nacional de Bibliotecas (SINABI) ${ }^{24}$ ha digitalizado un ejemplar, de manera que es posible observarlo y descargarlo en línea.

Luego de Vistas de Costa Rica, Calderón publica por un corto tiempo un boletín llamado "El Entreacto", cuyo primer número se presenta el 14 de abril de 1903. Este boletín cuenta con unas 8 planas y se dedicará a cubrir y reseñar las actividades y representaciones en el Teatro Nacional. En su presentación anota que: "...la importancia de la publicación es obvia, si se tiene en cuenta que no todos los asistentes á [sic] representaciones de ópera conocen el idioma y la trama de las obras." (Calderón Hernández, 1903, p. 1). Por supuesto, esta publicación dedicará un cuantioso espacio a la publicidad de negocios josefinos.

\subsection{Publicación de la Revista Páginas Ilustradas}

Para esta, su última empresa editorial, compartirá de nuevo con su hermano Francisco Calderón la propiedad de la revista, que llamarán Páginas Ilustradas, con periodicidad semanal, y aunque continuará en el cargo de director, como administrador estará su cuñado Antonio Argüello Valverde. Sus colaboradores para las secciones de la revista seguirán siendo de lo más selecto: Justo A. Facio, José Fidel Tristán, Anastasio Alfaro, entre otros.

El primer tomo saldrá a la luz el 1 de enero de 1904 y cerrará definitivamente el 18 de febrero de 1912, con ocho años, es la revista que tiene más tiempo de circulación ininterrumpida en la época, sobre todo si se rescata que, en sus inicios, carecía casi por completo de anuncios comerciales, su público meta

24 Se puede descargar en el siguiente enlace: http://www.sinabi.go.cr/biblioteca\%20digital/libros\%20 completos/Calderon\%20Prospero/Vistas\%20de\%20Costa\%20Rica.pdf 
era la elite de la capital costarricense, como el resto de las oligarquías urbanas centroamericanas, manteniendo su producción, en términos económicos, por medio de las cuotas de suscripción.

Aleccionado por su vasta experiencia como editor, y quizás intentando congraciarse con don Ascensión Esquivel presidente de entonces, dedica a él y a su gabinete la primera página del primer número, mediante un montaje fotográfico al estilo de la época; además, Gagini publica una comedia en un acto y en prosa titulada: Las cuatro y tres cuartos, cuya acción se desenvuelve en las cercanías del París de 1860; también, una composición para piano llamada: Lila de Eduardo Cuevas y un texto de Emilio Pacheco Cooper dedicado a Pio Víquez fallecido en 1899, quien había sido un asiduo colaborador de las anteriores revistas de Calderón. Únicamente, las últimas dos planas están dedicadas a anuncios comerciales, de un cuarto de página cada una; asimismo, durante ese primer año, la revista publica ilustraciones de Ezequiel Jiménez Rojas, así como fotografías de Rudd, Rudin y Tristán, entre otros

Más adelante, en 1906, Joaquín García Monge dirigía la sección literaria que recibía frecuentemente textos de Roberto Brenes Mesén, Rafael Ángel Troyo o Elías Leiva; de igual forma, los anuncios habían aumentado a cuatro planas, y algunas veces una de estas planas se imprimía sobre papel de color, como es el caso del número 79 de 1906, donde se menciona a Amando Céspedes Marín como Agente representante de las casas anunciadas en páginas llustradas.

En junio de ese mismo año, Calderón es sorprendido desagradablemente al embargársele su sueldo como profesor del Liceo de Costa Rica y del Colegio Superior de Señoritas. El embargo fue hecho por la señora María viuda de Lines, dueña de la Imprenta Lines, muy conocida en San José, que se anunciaba en esta revista y que se encargaba de su impresión. El editor adeudaba el dinero correspondiente a varios números, a pesar de haber vuelto de forma irregular la frecuencia de publicación, debido a los problemas económicos, para terminar, el embargo se levanta y se llega a una negociación.

En cuanto a la impresión, desde agosto de 1906 y al ver las dificultades económicas de Calderón, el presidente Esquivel autoriza para que se realice sin costo alguno en los Talleres de Tipografía Nacional; este cambio de imprenta y coste permiten modificaciones en las portadas, algunas se imprimieron como portadas falsas, es decir, totalmente decorativas, en dos tintas y con diseños Art nouveau, empastándose antes de la verdadera portada del número.

Podría decirse que la situación poco favorable para Calderón con la Imprenta Lines, propició avances en diferentes aspectos; por ejemplo, al mejorar la impresión gracias a la variedad de máquinas y posibilidades que brindaban los Talleres de Tipografía Nacional, se comenzaron a publicar fotomontajes con muchísima mejor calidad de impresión, también se dio un cambio favorable en la calidad del papel, muy en especial en el color, propiciando un avance significativo que influiría en otras publicaciones costarricenses (ver Figura 8 y Figura 9). 
FIGURA 8

Fotomontaje

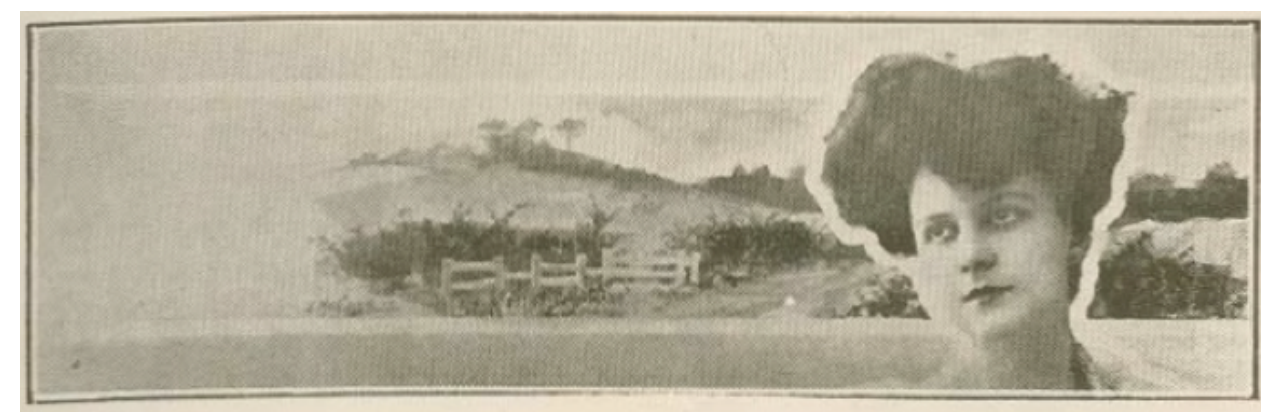

Fuente: Calderón Hernández (1908, p. 3057).

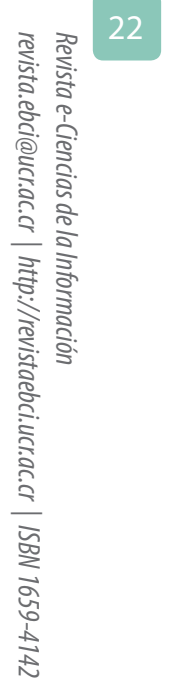

FIGURA 9

Falsa portada de las Páginas Ilustradas. Impresión a dos tintas realizada en los Talleres de Tipografía Nacional.

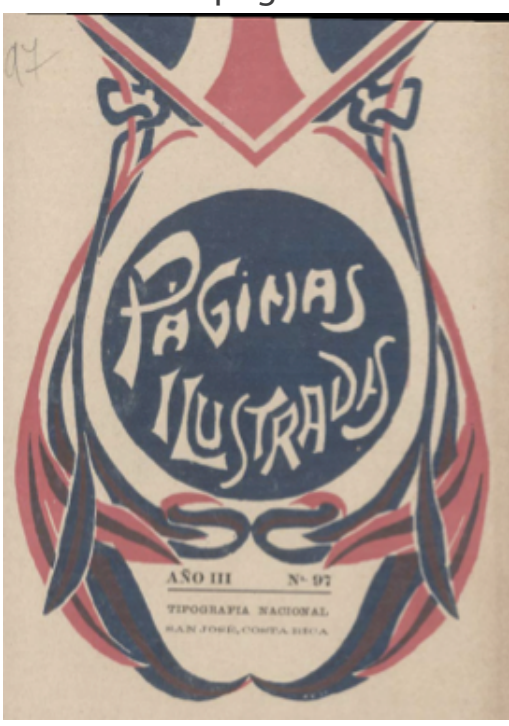

Fuente: Calderón Hernández (1906, p. 1).

En el número 97 correspondiente al 3 de junio de 1906, Calderón presenta un desglose de los movimientos monetarios de la publicación, con la intención de dejar claro, públicamente, que en realidad la revista no genera ganancias económicas, sino, más bien, se mantiene en circulación por el aporte del trabajo voluntario y convicción de los redactores y del propio Calderón. Incluso, la revista obsequia 200 ejemplares por semana al Museo Nacional de Costa Rica, quien se encarga de distribuirlos entre bibliotecas, museos e instituciones científicas de todo el mundo, convirtiéndose en una importante vitrina para las letras y la investigación científica del país.

Durante estos años, la Sección científica va adquiriendo notable importancia, con artículos y fotografías sobre botánica, zoología y geografía principalmente escritos, en su mayoría, por notables profesores de estos ramos, casi todos costarricenses o residentes en el país, como es el caso de Gustave Michaud y Anastasio Alfaro, y utilizados como material didáctico en los colegios. 
FIGURA 10

Laguna de Fraijanes. Autor: Próspero Calderón. Imagen de la Laguna de Fraijanes, recién formada luego del Terremoto de Fraijanes en diciembre de 1888 , junto con otras 6 imágenes más fue publicada por primera vez en el $n^{\circ} 8$, tomo 2, año 2 del 25 de enero de 1889 de Páginas Ilustradas. Abajo a la izquierda puede observarse la firma de Calderón.

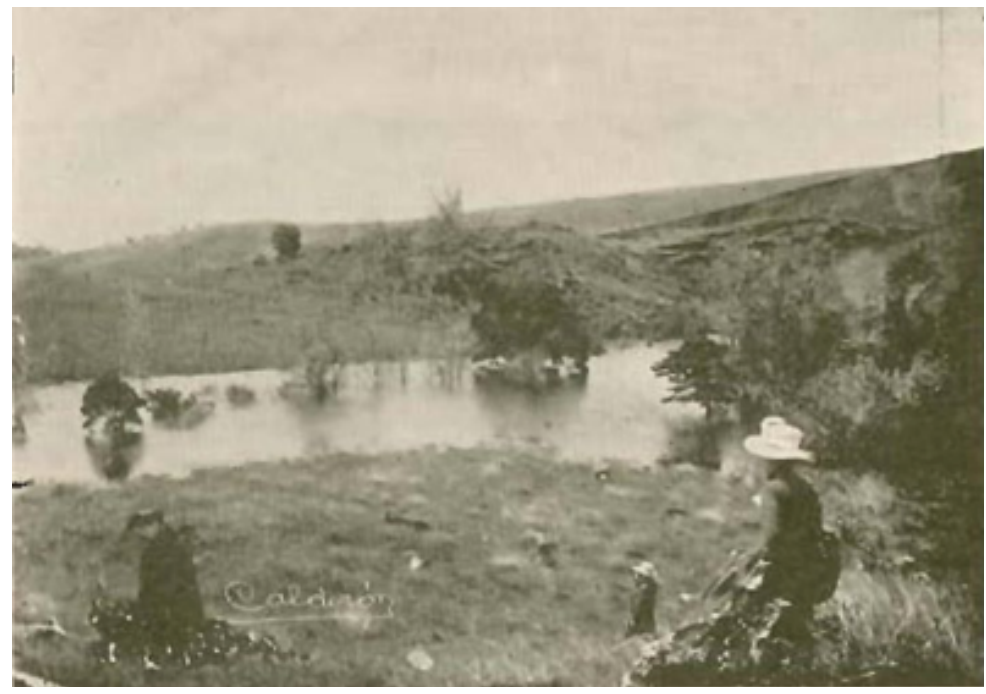

Fuente: Reproducción del archivo personal de la investigadora.

Estos artículos no van únicamente acompañados por ilustraciones manuales, como se había establecido en esa época, sino los especímenes o aspectos a estudiar son ahora fotografiados, por lo que se podría decir que las publicaciones de Calderón serán pioneras en el país tanto en lo correspondiente a divulgación científica, como también en la rama de la fotografía científica costarricense. Para ilustrar lo anterior, se adjunta una interesante fotografía que corresponde al surgimiento de la Laguna de Fraijanes, luego del terremoto ocurrido en esa zona en 1899, tomada y fotograbada por el mismo Calderón y que muestra incluso en medio de la masa de agua, los árboles que crecían en la hondonada antes de formarse la laguna (ver Figura 10).

También, será en esta Páginas llustradas que el joven poeta ramonense Lisímaco Chavarría, amigo de Calderón, regale al público con la publicación de la mayoría de su repertorio y le colabore con distintas secciones.

La publicación continúa con la línea de presentar de imágenes del paisaje costarricense, aunque mostrará con frecuencia hombres y mujeres de la elite josefina; igualmente, la poesía de autores centroamericanos, o traducciones de obras o poemas europeos, también, incluirá una variedad: la de dedicar cada tanto un número a alguna institución o actividad específica, aunque dedicaba algunas páginas a textos literarios, por ejemplo, la publicación del 15 de julio de 1906 es referida a la Imprenta Nacional, detallando sus dependencias, labores e historia, tanto en texto como en las imágenes de los empleados. Calderón heredó, con esto, un documento invaluable para la historia de la imprenta costarricense, cuyo único yerro es no haber consignado el nombre de los fotografiados.

Otro número especial es el 157 del 4 de agosto de 1907, donde la revista se dedica a la fundación del Ateneo de Costa Rica, pues, además de la 
importancia cultural, muchos de los fundadores colaboraban activamente con la revista, como su redactor Justo A. Facio y hasta el propio Calderón.

De los Estatutos del Ateneo se extrae su primer artículo que dice: “El Ateneo de Costa Rica es una asociación que tiene por objeto estimular el movimiento intelectual del país y contribuir al estudio de todos los problemas que interesen a la cultura científica literaria ó [sic] artística de la Nación" (Estatutos del Ateneo, 1907, p. 2516).

En este número se publica íntegro el texto que Justo $A$. Facio redactó para el hecho, así como el Acta de fundación firmada por célebres personajes interesados en el desarrollo cultural del país, entre ellos Napoleón Quesada, Enrique Echandi, Tomás Povedano, José Joaquín Vargas Calvo y Próspero Calderón. A doble página se presenta una fotografía de H.N. Ruud y fotograbada por Calderón que muestra a la recién fundada Directiva del Ateneo. En el número 165 del 29 de diciembre de 1907, Páginas llustradas se compromete a ceder, mensualmente, un número de su publicación al Ateneo y ser así su órgano de publicación oficial.

Para ese año, los colaboradores formales de la revista eran Anastasio Alfaro y José Fidel Tristán en la Sección Científica, Carlos González Rucavado y Daniel Ureña en la Sección Literaria, Teodoro Picado (Calibán) en la Sección Europea, Justo A. Facio (Gastón de Silva) en la Sección Social, Enrique Hine Saborío en la Revista de Revistas, y como corresponsal en Panamá, León Fernández Guardia. Otros aportes los dieron también García Monge y Carmen Lyra.

Los colaboradores fotográficos contaban con amplia experiencia en el tema y en el presente son considerados referentes históricos de la fotografía costarricense: H.N. Rudd, los hermanos Paynter, Fernando Zamora, Max Rudín y Federico Mora; el fotograbador, al igual que en sus otras publicaciones será Calderón.

El último número de esta revista se publicó el 18 de febrero de 1912, para ese entonces su valor de compra era de un colón y su entrega continuaba siendo semanal, los anuncios comerciales habían aumentado significativamente y se encontraban ahora entre los textos. La mayor parte de su publicación se destinaba a los suscriptores y una pequeña porción se vendía por pregón o en kiosco.

Para terminar, tanto Costa Rica llustrada como Páginas llustradas son consideradas precursoras tanto en su género como revistas, como por el trasfondo de sus publicaciones. Impactaron positivamente en el gusto de la población hacia el artículo cultural, la música, el teatro y las letras costarricenses y centroamericanas en general. Su aporte también es visible en la rama de las Artes gráficas, modernizando en el país la composición y la tipografía, así como las técnicas de fotograbado. Al mismo tiempo, fungió como plataforma para la visibilización de los pioneros de la fotografía artística, comercial y académica. 
FIGURA 11

Personal docente del Colegio Superior de Señoritas. Año 1907, Fotógrafo desconocido

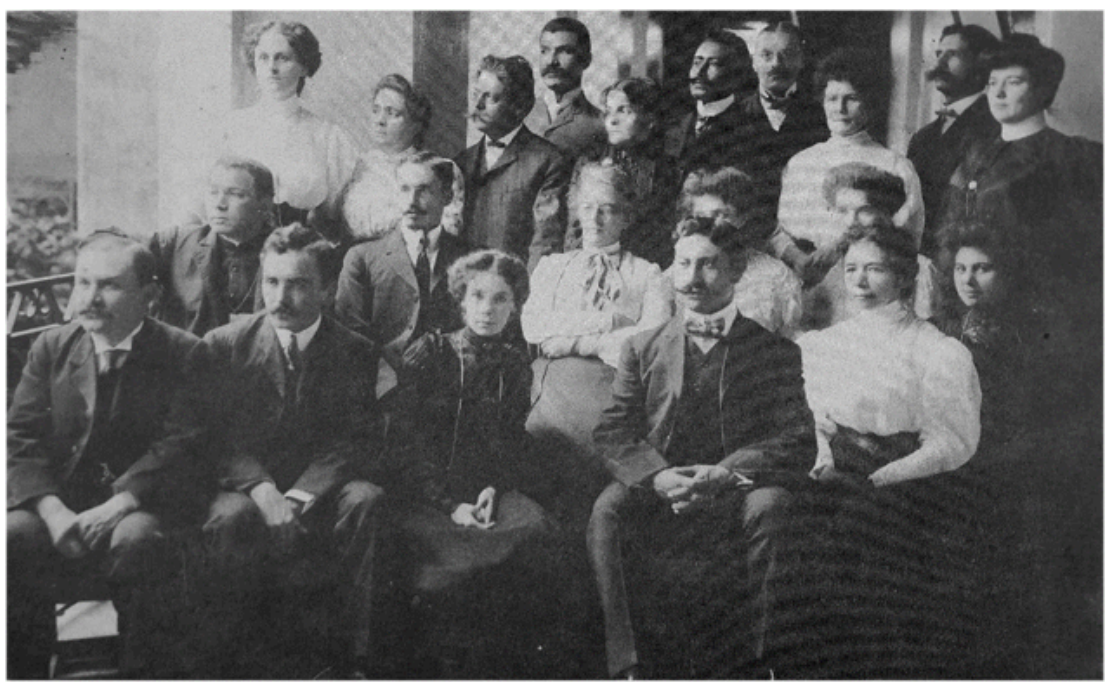

Nota: en la segunda fila de atrás hacia adelante y tercero de izquierda a derecha se puede observar a Próspero Calderón, profesor de Caligrafía y Dibujo; al centro, fila del medio sentada a Miss Marian Le Cappellain (Directora), junto a ella José Fidel Tristán Fernández (Sub-Director) y junto a él el Pbro. Francisco Zúñiga. Primera fila de izquierda a derecha sentado, José Joaquín Vargas Calvo (Profesor de Canto).

Fuente: Reproducción del archivo personal de la investigadora.

\section{4. ÚLTIMOS AÑOS}

Luego del cierre definitivo de sus últimas revistas ocurrido en 1912, Calderón se dedicó fundamentalmente a la docencia, y de forma intermitente a diferentes cargos públicos, tanto en el país como en el extranjero, aunque de igual manera relacionados con el campo de las Artes gráficas, de la edición y de la cultura en general.

En 1917, con motivo de la Exposición Nacional, Calderón presenta para concurso una ampliación a crayón del retrato del maestro Mauro Fernández Acuña -el original era un calotipo de H.N. Rudd-, ganando con él la Medalla de oro, tanto el calotipo como el crayón se encuentran en la actualidad en el Museo del Colegio Superior de Señoritas. Es de sobra conocido la predilección por parte de los concursantes de esta exposición por reproducir a Fernández Acuña, con la intención de congraciarse con Federico Tinoco -yerno de don Mauro- y en ese momento presidente de la República, luego del golpe de estado al gobierno de González Flores.

Al año siguiente y por menos de dos meses Calderón ocupa la dirección de la Imprenta Nacional en Costa Rica. En la misma época labora como ilustrador y fotógrafo independiente para distintas publicaciones e imprentas nacionales; también, fungió como Director de Archivos Nacionales y únicamente por cuarenta y cinco días el cargo de Director de la Biblioteca Nacional, mientras se daba la transición del cargo entre Carlos Gagini y Roberto Brenes Mesén.

Para el año de 1923 Calderón había dejado Costa Rica y vuelto a El Salvador, siendo Jefe del Taller de Fotograbados de la Imprenta Nacional de El Salvador (Andino y Andino, 1925), donde se le elogia por sus habilidades en la técnica, 
así como en el manejo del Departamento que dirige. Sus mayores logros en este puesto fueron modernizar, reorganizar y ampliar el taller a su cargo; además, ocupó interinamente la de Dirección, puesto que el 26 de enero de 1926 (Diario Oficial de El Salvador, 1929) se le dará en propiedad a Nicolás S. Villafuerte, trasladando a Calderón al cargo de Subdirector y a su puesto como jefe del Taller de fotograbados.

Regresa al país por algún tiempo y en 1930, la Secretaría de Instrucción Pública de Costa Rica (Actual Ministerio de Educación) publica un escalafón docente para todo el país, en las listas se señala que Próspero Calderón tiene 15 años laborando como profesor, luego de esto, pasará Calderón algún tiempo en Panamá, parece que debido a enfrentamientos con profesores extranjeros venidos al país, pues aunque tenía práctica en la docencia y conocimientos técnicos más que suficientes, carecía de titulación como profesor. En este país sería profesor del Instituto Nacional de Panamá, director y profesor de la Escuela para adultos.

Finalmente, volvería a San José donde moriría en 1934, a los 71 años de edad; dedicados casi en su totalidad a lo que más le apasionaba: la fotografía, las Artes gráficas y la cultura en general.

\section{EL LEGADO DE CALDERÓN}

Extraña que la figura de Próspero Calderón haya sido casi totalmente olvidada por el imaginario costarricense -la sociedad y sus relatores determinan el currículo histórico que se seguirá reproduciendo- aunque sus aportes artísticos y culturales continúan en boga, y como ejemplo están los cada vez más abundantes interesados en la herencia fotográfica de la Costa Rica de antaño publican constantemente imágenes tomadas de las publicaciones de Calderón, ${ }^{25}$ así como de su lente personal.

El Centro de Investigación en Identidad y Cultura Latinoamericanas (CIICLA) y la Biblioteca Nacional Miguel Obregón Lizano han dedicado esfuerzos y recursos al crear repositorios digitales de sus publicaciones para preservarlas y facilitar de estudio, ${ }^{26}$ mientras que estas también han sido objeto de análisis de investigaciones académicas, como las realizadas por las investigadoras Flora Ovares (Ovares, 1994 y 2004) y Florencia Quesada Avendaño (ver Figura 12).

Próspero Calderón puede ser considerado como el primer director y editor costarricense que se adentra en la creación y publicación del formato de revista, faena que conoció y practicó en cada una de sus facetas: iniciando por la búsqueda y edición de textos, la tipografía y el levantado de texto, la confección del dibujo y fotografía, así como el fotograbado de la imagen, pasando por el diagramado y composición de las páginas, la impresión, hasta llegar a la comercialización. Cada una de las partes de este largo proceso fue practicada y ejecutada por Calderón al iniciar cada nueva empresa editorial, dentro y fuera de Costa Rica.

Junto a Antolín Chinchilla ${ }^{27}$ serán de los pioneros en el estudio formal de los campos de la gráfica y el grabado, siendo de los primeros enviados por

25 Por ejemplo https://i.pinimg.com/originals/45/84/f7/4584f784d2de6466092a3460679edd95.jpg

26 Ver: http://www.ciicla.ucr.ac.cr/node/166 y http://www.sinabi.go.cr/contextual/busqueda. aspx?tipobuscador $=2$

27 Diseñador, tipógrafo, pintor y caricaturista, estudió en la Escuela de Artes y Oficios en Hamburgo, Alemania. 
el Estado para especializarse en estos campos, con la intención de que de vuelta al país no solo laboraran en la producción de textos nacionales, sino también para que compartieran la tecnología aprendida; ambos ocuparon diversos puestos públicos relacionados con el ámbito cultural. En el campo artístico, Calderón dejó manifestaciones en la técnica del dibujo, la fotografía y el diseño gráfico, que también compartió como docente.

De la misma forma, puede visualizarsele como el pionero en la promoción cultural costarricense, pues impulsó visionariamente y desde sus inicios a escritores de la talla de Lisímaco Chavarría y Manuel González Zeledón; a partir de sus propias revistas y por medio de la creación de concursos literarios, académicos y científicos también promovió a Anastasio Alfaro y José Fidel Tristán, y permitió la publicación de artistas y fotógrafos como Fernando Zamora, H.N. Rudd o Amando Céspedes Marín. En suma, Calderón propició la visibilización del país y su naturaleza,-insistimos- tanto dentro Costa Rica como en el exterior.

Finalmente, y como recomendaba el desaparecido maestro Luis Ferrero Acosta, se espera que tanto la memoria como el legado de Próspero Calderón Hernández sean valorados y recuperados para la posteridad. Es el momento de reunir de nuevo al artista con su obra.

FIGURA 12

Silueta de Próspero Calderón

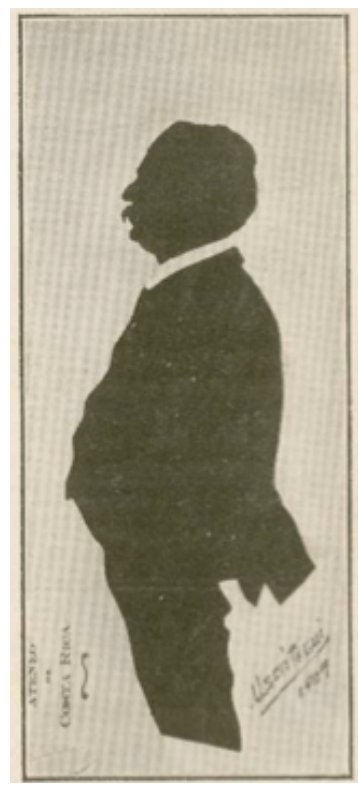

Fuente: Páginas llustradas, p. 3947. Reproducción en el archivo personal de la investigadora

\section{REFERENCIAS}

Alvarado I., Hernández, E. y Vargas, S. (2004) La mirada del Tiempo. Historia de la Fotografía en Costa Rica 1848-2003. Costa Rica, Fundación Museos del Banco Central. San José, Costa Rica.

Andino, M. y Andino, R. (1925). La Obra de gobierno del Dr. Quiñonez-Molina (1923-1925). San Salvador: Imprenta Nacional de El Salvador. 
Bazant, M. (coord.). (2013). Biografía. Métodos, metodologías y enfoques. México: El Colegio Mexiquense.

Calderón Hernández, P. (ed.). (12 de junio de 1887). [Portada de la separata y del primer número]. Revista quincenal de Ciencias, Arte y Literatura, 1(1). Recuperado de http://www.sinabi.go.cr/ver/biblioteca\%20digital/ revistas/costa\%20rica\%20ilustrada/costa\%20rica\%20ilustrada\%20 1887/01a-Costa\%20Rica\%20llustrada\%20Ano1,\%20n1\%20jun\%20 1887.pdf\#.WgzFrna71rR

Calderón Hernández, P. (15 de setiembre de 1892a). "Guatemala Ilustrada": prospecto. Guatemala Ilustrada: Revista de Ciencias, Arte y Literatura Centro Americanas, 1(1). Recuperado de http://ufdc.ufl.edu/ $\underline{\text { UF00091486/00001/1j?? }=\text { dloc }}$

Calderón Hernández, P. (ed.). (15 de setiembre de 1892b). Guatemala Ilustrada: Revista de Ciencias, Artes y Literatura Centro-Americana, 1(1). Recuperado de http://www.sinabi.go.cr/biblioteca\%20digital/libros\%20 completos/Calderon\%20Prospero/Vistas\%20de\%20Costa\%20Rica.pdf

Calderón Hernández, P. (1901). Vistas de Costa Rica. Impresa en las prensas de La República [Manuscrito inédito]. San José, Costa Rica. Recuperado de http://www.sinabi.go.cr/biblioteca\%20digital/libros\%20completos/ Calderon\%20Prospero/Vistas\%20de\%20Costa\%20Rica.pdf

Calderón Hernández, P. (ed.). (14 de abril de 1903). El Entreacto. El Entreacto, 1(1). San José, Costa Rica. Recuperado de http://www.sinabi.go.cr/ver/ biblioteca\%20digital/periodicos/El\%20entreacto/El\%20entreacto\%20 1903/dn-14\%20de\%20abril.pdf\#.WgT2M3a71rQ

Calderón Hernández, P. (2 de febrero de 1908). [Fotomontaje]. Páginas llustradas, 5(183). Recuperado de http://www.repositorio. ciicla.ucr.ac.cr:8080/bitstream/handle/123456789/526/PI-5-183. pdf? sequence $=1$ \&is Allowed $=y$

Calderón Hernández,P.(3 dejunio de 1906).[Falsa portada].Páginasllustradas, 3(97). Recuperado de http://www.sinabi.go.cr/ver/biblioteca\%20digital/ revistas/paginasilustradas/paginasilustradas 1906/01v-Ano\%203\%20 -\%20n.\%2097.pdf\#.WdHT78aQzIU

Calderón Hernández, P. (s.f.). [Silueta de Próspero Calderón]. Páginas Ilustradas, p. 3947

Calderón Hernández, P., y Soto, J. A. (12 de junio de 1887). "Costa Rica llustrada": prospecto [Separata]. Costa Rica llustrada: Revista quincenal de Ciencias, Arte y Literatura, 1(1). Recuperado de http:// www.sinabi.go.cr/ver/biblioteca\%20digital/revistas/costa\%20rica\%20 ilustrada/costa\%20rica\%20ilustrada\%201887/01a-Costa\%20Rica\%20 Ilustrada\%20Ano1,\%20n1\%20jun\%201887.pdf\#.WcxcWMaQzIU

Catálogo Exposición Nacional 1917. (1918). San José, Costa Rica: Imprenta Nacional.

El Artesano.1890, p. 3

Escobar Ohmstede, A. (2015). Mílada Bazant (coord.), Biografía. Métodos, metodologías y enfoques. Historia mexicana, 64(3). 
Estatutos del Ateneo de Costa Rica. (1907). Páginas Ilustradas, 4(154). Recuperado de http://www.sinabi.go.cr/biblioteca\%20digital/revistas/ paginasilustradas/Paginasilustradas 1907/02b-Ano\%204\%20-\%20 n.\%20157.pdf

FamilySearch.org. (9 de agosto de 2017). [Próspero Calderón. Información adicional en el registro de Josefina Emilia Calderón Arguello]. Recuperado de https://www.familysearch.org/ark:/61903/1:1:KF8K-7VN

Fernández Ferráz, J. (12 de junio de 1887). Costa Rica Ilustrada. Costa Rica Ilustrada: Revista quincenal de Ciencias, Arte y Literatura, 1(1). Recuperado de http://www.sinabi.go.cr/ver/biblioteca\%20digital/ revistas/costa\%20rica\%20ilustrada/costa\%20rica\%20ilustrada\%20 1887/01a-Costa\%20Rica\%20llustrada\%20Ano1,\%20n1\%20jun\%20 1887.pdfH.WCXcWMaQzIU

Ferrero Acosta, L. (2004). Sociedad y Arte en la Costa Rica del Siglo XIX. San José, Costa Rica: Editorial EUNED.

Fusco, G. (2009). La investigación Histórica, evolución y metodología. Revista Mañongo, 17(32).

Gagini, C. (1961). Al través de mi vida. San José, Costa Rica: Editorial Costa Rica.

Gagini, C. (febrero, 1890). Proyecto, nota en Revista El Artesano.

Martínez, J. A. (2001). Historia de la edición en España 1836-1936. Madrid, España: Edit. Marcial Pons y Ediciones de Historia.

Ovares, F. (1994). Revistas literarias en Costa Rica, 1890-1930. Heredia, Costa Rica: Editorial Universidad Nacional de Costa Rica.

Ovares, F. (2004). Crónicas de lo efímero: un siglo de revistas culturales y literarias costarricenses. Revista Iberoamericana, 70(208-209).

Pérez Brignoli, H. (2010) La población de Costa Rica 1750-2000. San José, Costa Rica: Editorial UCR.

Quesada Avendaño, F. (2007) La modernización entre cafetales: San José, Costa Rica, 1880-1930 (tesis doctoral inédita). Facultad de Humanidades, Universidad de Helsinki, Finlandia.

Recopilación de las Leyes de la República de Guatemala 1892-1893 (tomo XI). (1894). Guatemala: Tipografía Nacional. Recuperado de https:// archive.org/details/recopilacinde11 unseguat

Rudd, H. N., y Calderón Hernández, P. (1907). Ateneo de Costa Rica: Directiva [Fotografía]. Páginas Ilustradas, 4(57). Recuperado de http:// www.sinabi.go.cr/biblioteca\%20digital/revistas/paginasilustradas/ Paginasilustradas1907/02b-Ano\%204\%20-\%20n.\%20157.pdf

Sánchez Zumbado, J. (2013). Las láminas de dibujo de la Escuela Nacional de Bellas Artes. Revista Humanidades, 3. Recuperado de https://revistas. ucr.ac.cr/index.php/humanidades/article/view/13067 
Secretaría de Gobernación, Policía y Fomento. (1892). Memoria de la Secretaría de Gobernación, Policía y Fomento del año de 1891. San José, Costa Rica: Tipografía Nacional.

Urbina Gaitán, C. (2013). Las exposiciones Nacionales de Costa Rica 19171918. Revista de Ciencias Sociales, Editorial Universidad de Costa Rica. San José, Costa Rica

Vega J. P. (1996). De periodista a literato: los escritores de periódicos costarricenses (1870-1890). Anuario de Estudios Centroamericanos, Universidad de Costa Rica. San José, Costa Rica.

Vega J. P (2004). Los responsables de los impresos en Costa Rica (19001930). Revista de Historia, $n^{\circ}$ 49-50, UCR. San José, Costa Rica

Zavaleta Ochoa, E. (2002). Imágenes de la vida cotidiana costarricense (19001940) una colección de dibujos de Enrique Echandi. Ponencia presentada en el VI Congreso Centroamericano de Historia, CIICLA, UCR. 


\section{e $\begin{aligned} & \text { e-Ciencias de la } \\ & \text { Información }\end{aligned}$}
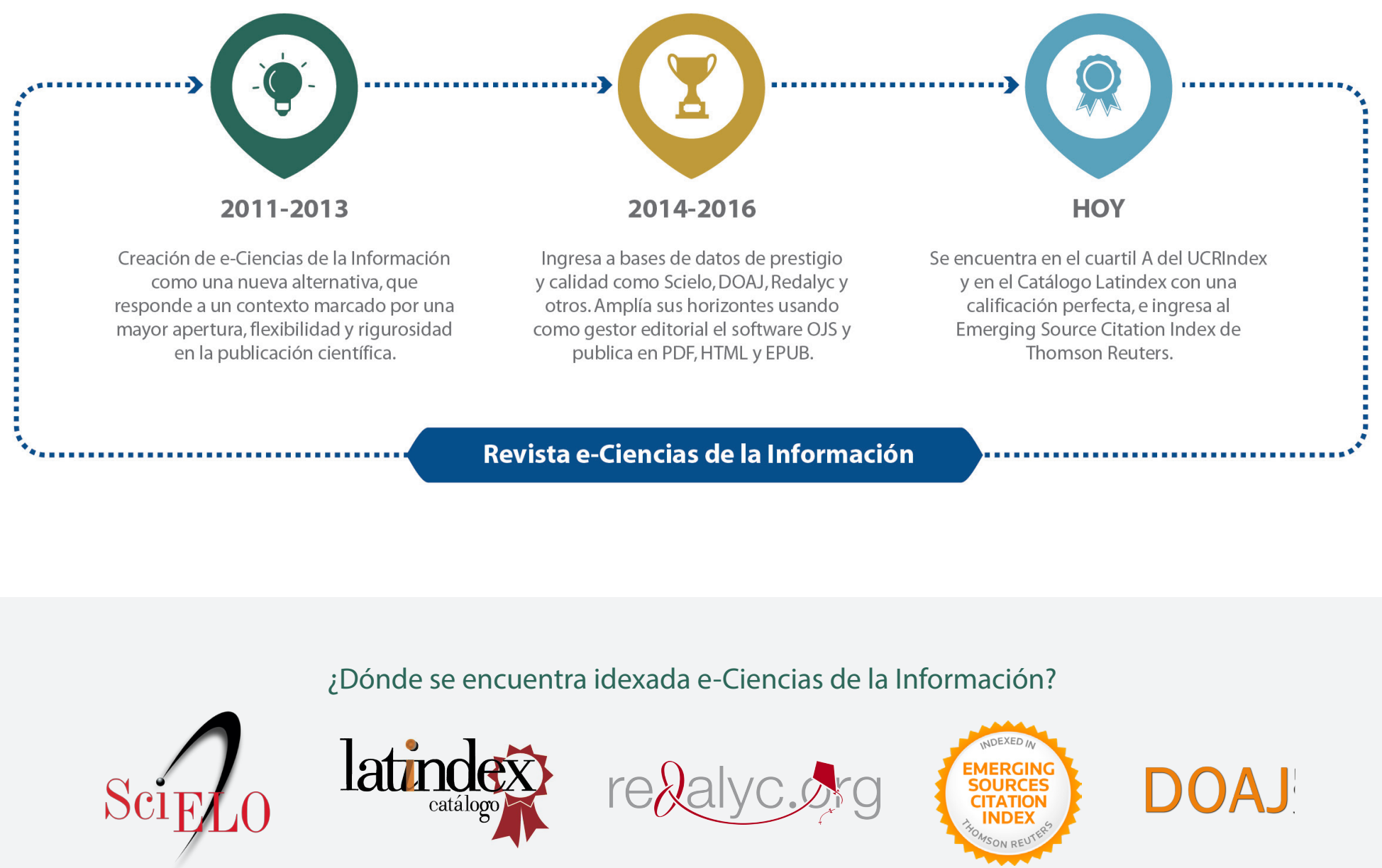

¿Dónde se encuentra idexada e-Ciencias de la Información?
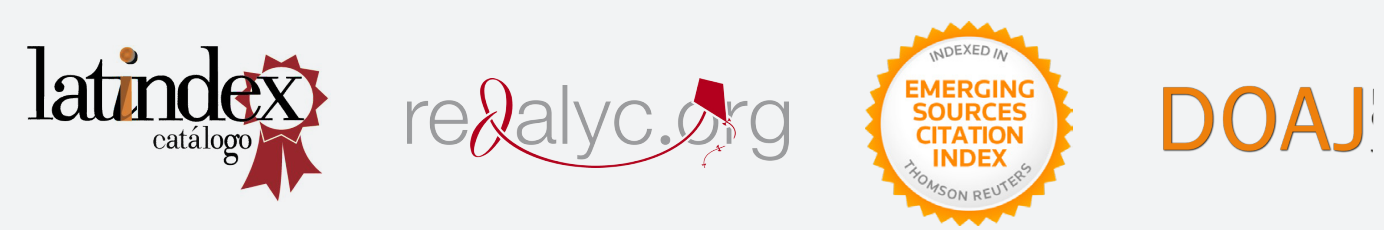

Para más información ingrese a nuestra lista completa de indexadores

¿Desea publicar su trabajo?

Ingrese aquí

O escríbanos a la siguiente dirección

revista.ebci@ucr.ac.cr 